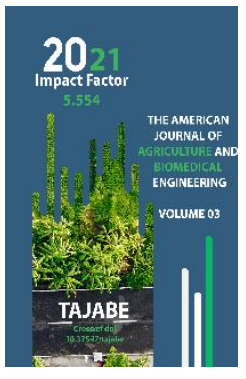

Copyright: Original content from this work may be used under the terms of the creative commons attributes 4.0 licence.

\section{Studying The Classification And Quality Of Food}

\author{
Kurbonkul Mavlankulovich Karimkulov \\ Doctor Of Technical Sciences, Professor, Customs Institute Of The State Customs Committee \\ Of The Republic Of Uzbekistan, Tashkent, Uzbekistan
}

Ikromjon Esanboyevich Uzohkov

Applicant, Almalik Branch Of The Tashkent State Technical University Named After Islam Karimov, Almalyk, Uzbekistan

Madraim Khasanovich Sarikulov

Senior Lecturer, Almalik Branch Of The Tashkent State Technical University Named After Islam Karimov, Almalyk, Uzbekistan

\title{
ABSTRACT
}

This article examines the analysis of the quality of food products in the world markets. The negative impact of low-quality goods on the health of the population and the economy of the country is substantiated, as well as issues of studying modern methods for determining the composition of lowquality goods.

\section{KEYWORDS}

Foodstuffs, low-quality foodstuffs, chemical composition, the nomenclature of commodity groups, customs expertise.

\section{INTRODUCTION}

Today in the Republic of Uzbekistan more than $51 \%$ of the population lives in rural areas.
However, the share of agricultural products in the country's GDP does not exceed $17 \%$, while 
the volume of processing of agricultural products is less than $10 \%$. However, in developed countries, this figure exceeds 50 per cent. As you know, in the Strategy of Action for the Development of the Republic of Uzbekistan for 2017-2021, tasks are outlined for the effective use of local raw materials and the introduction of advanced intensive methods, innovative ideas and technologies in production. This work is devoted to the solution and implementation of these tasks in practice.

Since food is one of the basic human needs, therefore, all countries produce, import or export these products. All goods related to food products are usually divided into corresponding positions of commodity groups. For example, heading of heading 04 includes dairy products, bird eggs, natural honey and other unspecified or unregistered pet foods. Germany is the world's largest importer of this group of goods. Of the total volume of world imports of group 04 goods, Germany accounted for $10.4 \%$ of the turnover in 2017 , which amounted to 9.3 billion US dollars, and in 2018 reached $10.5 \%$, which corresponded to 9.5 billion US dollars. ... Germany imports from Holland milk, cheese, natural honey and butter. The largest exporter of group 04 goods is China, i.e. such food products as milk, butter, natural honey and bird eggs in more than 80 countries. The main consumers are New Zealand, Australia, the USA, France and Germany. Also, the largest exporters of group 04 goods are the USA, France, the Netherlands, Belgium and New Zealand,

According to experts in the field of production and consumption of food, about 567 billion eggs are consumed worldwide every year. These food products, i.e. eggs are fried, boiled, made cocktails and even drunk. The quality issues of these products are considered the main criterion.

Group 02 goods, i.e. meat and meat products are also some of the most consumed foods in the world. In 2017-2018, China was the largest importer of this group of goods. In 2017, China imported $8.03 \%$ of product group 02, i.e. meat and meat products, and in 2018 8.8\% of all imported goods in the world. The Chinese state mainly imports products of position 0202 (frozen black beef). The world's leading exporters of meat and meat products are the USA, Brazil, the Netherlands and Germany. The USA mainly exports to Japan, Canada, China, Mexico goods of groups 0203 (fresh, frozen, chilled pork), 0201 (fresh, chilled black beef), 0207 (fresh, chilled, frozen poultry meat and intestines specified in position 0105), 0202 (frozen black beef), 0206 (fresh, frozen, chilled black beef, pork, sheep, goat, horse meat, donkey and mule intestines).

The composition of food products belonging to commodity group 21 includes a wide range of consumer products. These foods are considered essential for the daily needs of people. The export of this group of goods in the world in 2017 amounted to \$ 69.4 billion, and in 2018 - $\$ 77.5$ billion. The largest exporters of these products are the USA, Germany, the Netherlands, Singapore and China. The group of 21 items exported from these countries accounted for $35 \%$ of all world exports in 2017 and $38 \%$ in 2018. The USA, Great Britain, France, China, Germany and Canada are the leaders in the import of this group of goods.

I would like to note that the export of goods from the Republic of Uzbekistan is growing from year to year. In recent years, several positive steps have been taken in our country to grow vegetables and fruits. As a result of 
this work, the volume of exports of goods of group 07 (vegetables and root crops) increased. In 2017-2018, Uzbekistan rose to 7th place in the world in terms of the volume of exports of this group of goods. Exports from Uzbekistan of group 07 goods in 2017 reached $\$ 3.4$ billion, and in 2018 - \$ 3.2 billion. Uzbekistan exports these types of products to countries such as China, Afghanistan, Russia and Kazakhstan.

In recent years, comprehensive reforms have been carried out in our country, including a radical improvement of the customs service of the Republic of Uzbekistan. In addition, the volume of exports and imports from our country is growing from year to year. According to the official website of the World Trade Organization www.trademap.org. noted that in 2018 the import of goods amounted to 12.03 billion US dollars, and in 2018 it reached 17.3 billion US dollars. As you can see from these figures, the volume of imports in 2018 increased by $43 \%$ compared to 2017 . Of these, the largest number is occupied by goods of 84 groups, i.e. household appliances goods. Imports of these goods in 2017 amounted to USD 2.7 billion, and in 2018 reached USD 4.5 billion. Among food products (in the 10th place) are goods of the 17th group, i.e. sugar and confectionery in 2017 amounted to USD
0.33 billion, and in 2018 it amounted to USD 0.35 billion. Of these, heading 1701 (sugar) accounted for USD 0.33 billion in 2017, and USD 0.34 billion in 2018. In 2017-2018, the share of food products amounted to about 9-12\% of all imported goods. Exports of goods from the Republic of Uzbekistan in 2017 amounted to USD 10.07 billion, and in 2018 reached USD 10.91 billion. The most exported commodity group 07 - agricultural products in 2017 amounted to USD 3.5 billion, and in 2018 it amounted to USD 3.2 billion. These data indicate that the main share of exports and imports from the Republic of Uzbekistan is food.

It should be noted that the development of international economic relations contributes to the sustainable growth of exports, which in turn creates the basis for achieving certain results. In particular, in 2019, the number of enterprises engaged in the export of goods and services increased by 1,172 compared to the same period of the previous year, and their total number was 5,438. (Source: Information from the State Statistics Committee of the Republic of Uzbekistan - https://stat.uz/uz/). Figure 1 provides information on goods and services carried out in the Republic of Uzbekistan in 2019 (in\%). 


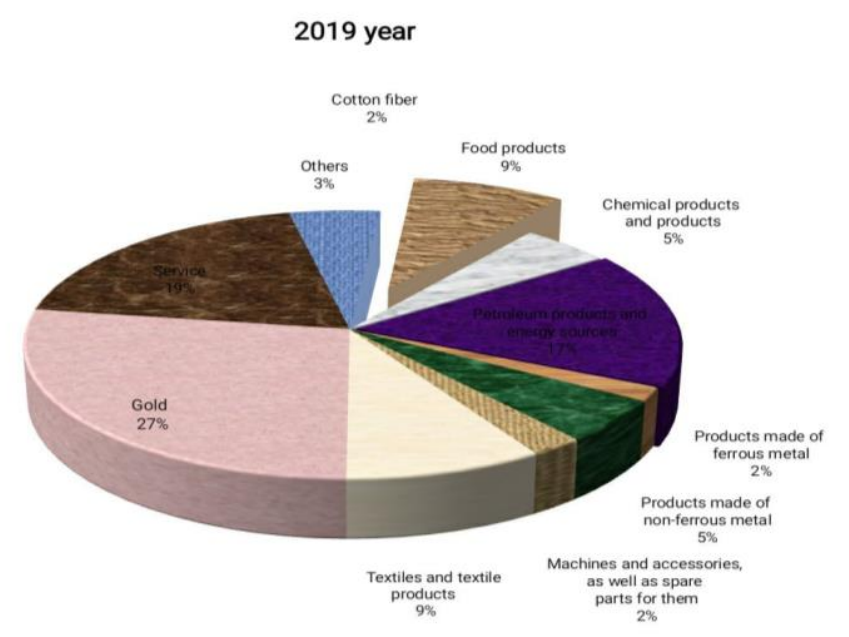

Fig.1. Diagram for the distribution of goods and services in the Republic of Uzbekistan for 2019 (in\%).

The introduction of a risk management system in the customs authorities led to the simplification of the principles of customs procedures. This, in turn, helps to save time, creating certain conveniences for participants in foreign economic activity. Not all participants in external economic activity benefit from the created opportunities. There are a number of violations of customs rules on the incorrect determination of the code of goods for the customs nomenclature of foreign economic activity. In recent years, several problems have arisen with the classification of food products according to the customs nomenclature of foreign economic activity. For example, several years ago, dairy products and milk powder were classified according to the customs nomenclature of foreign economic activity code 0402101100 and submitted to the customs authorities as a cargo declaration. The amount of starch in milk powder classified in position 0402 on the customs nomenclature of foreign economic activity must be less than $5 \%$. Otherwise, if the amount of starch in milk powder is $5 \%$ or more, such a dairy product should have been assigned to item 2106. As a result of a customs inspection carried out in a customs laboratory, it was found that the starch content of this product did not contain more than five\%. Thus, on the basis of the analyzes carried out in line with the customs nomenclature of foreign economic activity, it was concluded that these goods should be classified in the position according to the customs nomenclature of foreign economic activities with the following code 2106909200.

Rice was classified under code 1006101000 according to the customs nomenclature of foreign economic activity and was registered in the customs import in the form of a cargo declaration. Samples were transferred to the customs authorities instead of rice, brown rice, which differed from the samples intended for customs authorities, that is, not related to imported goods. Samples of ready-to-eat rice products were presented to the certification bodies. When inspecting 840 tons of imported products, the customs laboratory staff found out that the samples taken for examination did not correspond to the certificates. As a result, 
it was concluded that the product is a ready-toeat rice product and its correct code for the customs nomenclature of foreign economic activity must correspond to code 1006102700 . As another example, SMAK Potato Chips, classified according to the customs nomenclature of foreign economic activity code 200520200 and submitted to the customs authority with a customs cargo declaration for import, are considered. Sliced potato products classified in heading 2005 are in the form of rectangular plates, made from potato flour and contain a small amount of salt and sodium glutamate. These potatoes should be fried a few seconds before eating. As a result of the customs examination carried out in the customs laboratory, it was established that potato chips "Potato chips SMAK" and other types of flour-starch mixture, before being served ready-made, are subjected to cutting in the form of thin rectangles on special equipment, then cut into thin layers, followed by a sprinkle of salt, aromatic spices and fried. In accordance with the text of heading 1905 and the basic rules of interpretation for the customs nomenclature of foreign economic activity, a corresponding conclusion was prepared for the product "Potato chips SMAK", which is classified by code 190590550 in the line of the customs nomenclature of foreign economic activity.

\section{RESULTS OF STUDIES}

As shown by the analysis of the research carried out on the customs nomenclature of foreign economic activity, it was revealed that the departments of territorial customs laboratories do not have instruments for determining the chemical composition and quality of exported and implanted goods. All this, in turn, creates a number of problems for the laboratory staff.
As far as we know, according to Article 217 of the Customs Code, an examination can be carried out either by one (customs examination commission) or by several experts of different specialities (complex customs examination). However, the uneven distribution of specialists across regions can create certain problems for conducting a comprehensive examination.

I would like to note that high rates of customs duties have been established for a number of food products, and some goods are exempted from customs duties. For example, in accordance with the Decree of the President of the Republic of Uzbekistan No. PF-5978 dated April 3, 2020, a list of goods exempted from customs duties and excise taxes was provided until December 31, 2020. The list also included goods in positions 0402, but not goods in positions 2106. According to the decree of the President of the Republic of Uzbekistan PQ3818 dated June 29, 2018, the import customs duty for goods in position 2106 was set at $30 \%$. Above, we examined the problems arising in the classification of certain food products in accordance with the requirements of the customs nomenclature for foreign economic activity. It should be noted that milk substitutes and dry milk products classified under code 2106909200 should be classified under code 0402 101100. Taking into account the above, it can be argued that at this stage of our time the main factor is the health of the population, based on this, all work should be carried out in the direction of production and quality control of food.

\section{REFERENCES}

1. Andreeva E. I. (2016). Development of the methodology and improvement of the mechanism. Managing the identification of goods for customs 
purposes: Monograph, M.: EPD Russian

Customs Academy. 202 p.

2. www.lex.uz - National database on the legislation of the Republic of Uzbekistan.

3. www.stat.uz - portal of the State Committee of the Republic of Uzbekistan on Statistics

4. Gail L., Kramer, Clarence W. Jensen, Douglas D. Southgate Jr. (2001). Agricultural economics and agribusiness. New York, $519 \mathrm{p}$.

5. Ibragimov U. K. (2002). Evaluation of antioxidants-food additives. STANDARD. (1)1. p.58-59.

6. Commodity nomenclature of foreign economic activity of the Republic of Uzbekistan. 2017 y. version. Tashkent. 2017, 655 p.

7. S. Gibilisco. (2010). Alternative energy without secrets. Stan Gibilisco; [translated from English. A.V. Solovieva]. Moscow. Eksmo. 368 p. (There are no secrets).

8. Korf, D. V. (2017). Legal regulation of classification of goods: on the example of the Commodity nomenclature of foreign economic activity of the EAEU. Publichno-pravovye issledovaniya, (1), 32-45.

9. Fidaev, D. T., Khunarov, A. M., \& Kuchkarova, N. X. (2021). Air pollution and its consequences for human health. Academic research in educational sciences, 2(2).

10. Adilov, T. T., Fidaev, J. T., Khunarov, A. M., \& Kuchkarova, N. X. (2020). Use Of Natural-Territorial Resources In Solving Environmental Problems. The American Journal of Engineering and Technology, 2(11), 75-80.

11. Nazirova, R. M., Usmonov, N. B., \& Bakhtiyorova, D. (2020). Innovative technologies for grain storage of different crops. Academicia: An International Multidisciplinary Research Journal, 10(6), 222-228.

12. Muxkharovna, N. R., Akhadovich, K. A., Mukhiddinovich, T. S., \& Rakhmatjanovna, M. S. (2020). Investigation of solubility kinetics and interaction of stabilizing additives in production of complex fertilizers based on granular nitrate and stabilizing additives. Academicia: An International Multidisciplinary Research Journal, 10(5), 657-664.

13. Abdurakhmonova, N. K., Nazirova, R. M., \& Mirsalimova, S. R. (2020). Phosphoric-potash fertilizers based on sulfuric acid processing of phosphorite flour and potassium chloride. Academicia: An International Multidisciplinary Research Journal, 10(10), 252-255.

14. Muxtarovna, N. R., Mukhtarovich, T. S., \& Saydiaxral, T. (2016). Phosphoruspotassium and nitrogen-phosphoruspotassium fertilizer based on washed and dried concentrate from central Kyzylkum phosphorite. Austrian Journal of Technical and Natural Sciences, (9-10).

15. Nazirova, R., Usmonov, N., \& Askarov, K. (2020). Technology of storing grain in a cooled state. Збірник наукових праць $\Lambda^{\prime} О Г О \Sigma$, 93-95.

16. Holliev, E. (2011). Drought and Cotton Varieties in Zaravshan Valley of Uzbekistan. International Journal of Applied, 6(3), 217-221.

17. Ergashovich, K. A., Davronovich, K. Y., Toshtemirovna, N. U., \& Azamatovna, B. Z. (2020). Effect of soil types, salinity and moisture levels on cotton 
The American Journal of Agriculture and Boimedical Engineering (ISSN - 2689-1018)

Published: March 30, 2021| Pages: 32-38

2021: $5 \cdot 554$

Doi: https://doi.org/10.37547/tajabe/Volume03Issue03-06

OCLC - 1121105746

productivity. Journal of Critical

Reviews, 7(9), 240-243.

18. Ergashovich, K. A., Toshtemirovna, N. U., Rakhimovna, A. K., \& Abdullayevna, F. F. (2020). Effects of Microelements on Drought Resistance of Cotton Plant. International Journal of Psychosocial Rehabilitation, 24(2).

19. Davronovich, K. Y., \& Ergashovich, K. A. (2019). Growing of cotton varieties and hybrid to the height under the ecological conditions of soil salinity and washed soil salinity. Asian Journal of Multidimensional Research (AJMR), 8(9), 84-89.

20. Toshtemirovna, N. U., \& Ergashovich, K. A. (2019). Regulation of the water balance of the cotton varieties under salting conditions. Academicia: An International Multidisciplinary

Research Journal, 9(8), 5-9. 